\title{
Genetic Variation of Rabbit Fish (Siganus canaliculatus Park, 1797) In the waters of Bone Bay and Makassar Strait
}

\author{
Sahabuddin ${ }^{1}$, Andi Iqbal Burhanuddin ${ }^{2}$, Ambo Tuwo ${ }^{3}$, Asmi Citra Malina ${ }^{4}$
}

"Doctoral Student, Hasanuddin University/Marine Sciences and Aquaculture, Makassar, South Sulawesi, Indonesia

${ }^{2}$ Professor of the Department of Marine Sciences and Aquaculture, Hasanuddin University, Makassar, South Sulawesi, Indonesia

${ }^{3}$ Professor of the Department of Marine Sciences and Aquaculture, Hasanuddin University, Makassar, South Sulawesi, Indonesia

${ }^{4}$ Lecturer of the Department of Marine Sciences and Aquaculture, Hasanuddin University, Makassar, South Sulawesi, Indonesia

\begin{abstract}
This research aims to study the genetic variation of Rabbit fish in the waters of Makassar Strait and Bone Bay with Random Amplified Polimorfhic DNA (RAPD) method. The Rabbit fish samples obtained from three population, Makassar Strait waters (Parepare and Takalar) and Bone Bay waters (Luwu Regency). 9 fish from each population preserved with TNES urea buffer solution. Extraction of genomic DNA with Phenol-chloroform method. Between seven primer screenings, four primer selected for RAPD analysis. Genetic variation analyzed using TFPGA software (tool for population genetic analysis). The genetic relationship presented in dendogram. The research shows that the genetic variation of the fish (Siganus canaliculatus) with RAPD analysis resulting the highest similarity indeks (0.8644) obtained between Parepare and Takalar waters population, and the lowest (0.7290) between Parepare and Luwu waters population. The closest genetic relationship obtained from Parepare and Takalar waters population 0,1458 while the farthest obtained from Luwu and Parepare waters population with 0.3161 score. According to the genetic relationship obtained two main groups that are Makassar Strait and Bone Bay population. The two population in the Makassar Strait are the same group and separated from Bone Bay population.
\end{abstract}

Keywords : Genetic Variation, Rabbit Fish, Siganus Canaliculatus, Similarity Index

\section{INTRODUCTION}

Rabbit fish from the Siganidae family has a diversity of species that are scattered in different territorial waters in Indonesia, especially shallow waters or corals. Fish from this family consists of one genus, Siganus, which has 17 species in Indonesia (Iwatsuki et al., 2000; Director General of Fisheries, 2001; Carpenter, 2001). Yunus (2005) found 13 species in Spermonde waters, while (Burhanuddin et al., 1979; Burhanuddin et.al., 2006) found 17 species from the Siganidae family.

Rabbit fish (Siganus) fishing activities in the waters of Makassar Strait and Bone Bay continue to increase, causing exploitation pressure on the fish which is indicated by the number of catches decreasing. According to Jalil, et al., (2001) fish catches of Siganus canaliculatus in Luwu Regency have decreased in size 
over time. Besides fishing in the area has passed the sustainable value, which if carried out continuously will cause extinction, continuous fishing efforts cause a decrease in business unit production from $100 \mathrm{~kg} /$ trip to $15-30 \mathrm{~kg}$ / trip. Whereas Lante (2010) stated that rabbit fish production decreased from 955.2 tons to 121.4 tons in 2007 in the Makassar Strait and Bone Bay.

The decline in aquatic resource production needs special attention with management. One basis for managing aquatic resources is to analyze genetic variation within a population to determine the characteristics of the resources to be managed. Genetic diversity is the lowest hierarchy in terms of biodiversity and is an important key for a species to survive, to maintain population sustainability and to increase productivity of a species (Soewardi, 2007). Genetic diversity is important information in the short and long term for a population (Ferguson et al., 1995). Furthermore permana et al. (2007) stated that within populations genetic diversity is an important biological resource to know and has benefits for determining seedling strategies, especially in determining prospective broodstock that have high genetic quality.

Random Amplified Polymorphic DNA (RAPD) is a method commonly used to analyze fish genetic diversity with the application of Polymerase Chain Reaction (PCR). Where PCR is used to amplify DNA and to find out the polymorphic differences in DNA that exist between species or individuals. The DNA polymorphism method is considered to have a high degree of accuracy compared to other methods because it is not affected by environmental changes and the strand structure is distinguished by the sequence of nucleotide bases in DNA. The advantage of RAPD from other markers is that it is relatively simple, easy to prepare, faster results, and does not require background information of the organism genome to be studied (Williams et al., 1990).
Analysis of the genetic variation of various types of fish has been done by several researchers including: flying fish (Fahri, 2001); rat grouper fish (Irmawati, 2003; Wahidah 2004); kancra fish (Nugroho et al., 2006); carp (Nugroho and Kusmini, 2007); yellow fin tuna (permana et al., 2007); Siganus guttatus fish (Lante et al., 2011); and Lais fish (Jusmaldi, 2016). But until now there is still little data and information about the genetic variation of Rabbit fish (Siganus canaliculatus) especially from the Makassar strait and the Bone bays waters. In maintaining the sustainability and efforts to develop and to manage the fish management, it is necessary to have the basic information about the genetic character of the population in both waters. This study aims to examine the genetic variation of Siganus canaliculatus fish populations in Makassar Strait and Bone Bay.

\section{METHODS AND MATERIAL}

\section{Sample Fish}

Fish samples used in this study were taken from three waters locations, namely the Makassar Strait waters (Parepare and Takalar), and Bone Bay (Luwu) (Figure 1). For the analysis of genetic variation in this study using 3 fish samples from each population. Around 50 mg taken from every fish, then preserved using $250 \mu \mathrm{L}$ TNES urea buffer in a $1.5 \mathrm{~mL}$ eppendorf tube (Asahida et al., 1996). Then, the eppendorf tube containing the sample is put in a container to be brought to the laboratory and stored at room temperature until the DNA extraction is carried out. 


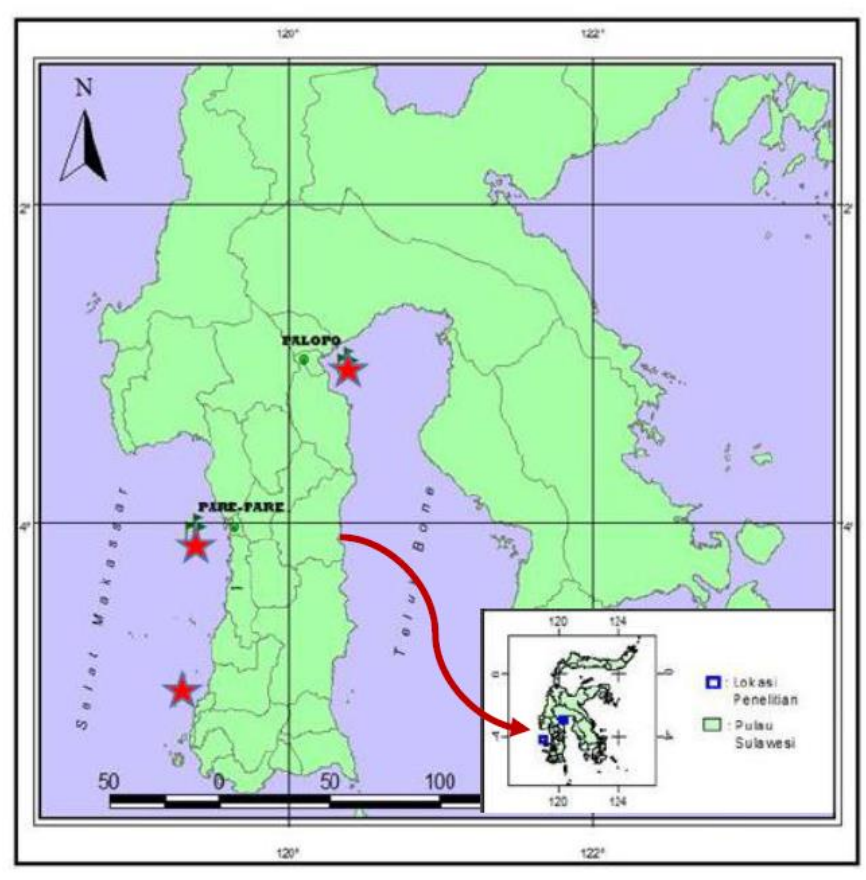

Figure 1. Sampling locations

\section{DNA Genome Extraction}

The method used in DNA extraction is the PhenolChloroform method (Parenrengi, 2001). The extracted organ is the fish meat, added $500 \mu \mathrm{l}$ buffer lysis $(0.5 \mathrm{M}$ NaCI, 0.001 M EDTA, 1\% (W / V) SDS, 0.8\% (V / V) Triton X-100, and 0.1 M Tris-HCL pH 9.0) were then put into a $1.5 \mathrm{~mL}$ eppendorf tube and added $40 \mu \mathrm{L} \mathrm{10 \%}$ (W / v) SDS and $20 \mu \mathrm{L}$ proteinase-K $(20 \mathrm{mg} / \mathrm{mL}$ solution).

The sample incubated at $55^{\circ} \mathrm{C}$ for $1-3$ hours, $12.5 \mu \mathrm{L}$ (20 $\mathrm{mg} / \mathrm{mL}$ solution) RNase was added and then stored at room temperature for 15-30 minutes. Samples were added with phenol: chloroform: isoamyl alcohol (PCI: 25: 24: 1) and then vortexed slowly until homogeneous. Then the samples were left at room temperature for 10 minutes, then centrifuged at a speed of 13,000 rpm for 8 minutes. The $750 \mu \mathrm{L}$ liquid supernatant was transferred to a new $1.5 \mathrm{~mL}$ eppendorf tube, then 500 PCI (25: 24: 1) was added. After that the sample was left at room temperature for 10 minutes then centrifuged at a speed of $13,000 \mathrm{rpm}$ for 4 minutes.

A total of $600 \mu \mathrm{L}$ of the supernatant transferred to a new $1.5 \mathrm{~mL}$ eppendorf tube. Then, a mixture of Chloroform: Isoamyl Alcohol (24: 1) added and centrifuged at 13,000 rpm for 4 minutes. $400 \mu \mathrm{L}$ supernatant added with a cold solution of ethanol as much as twice of the sample volume and then centrifuged at a speed of $6,000 \mathrm{rpm}$ for 30 minutes. The supernatant is removed, then the base layer (pellet) is added with $70 \%$ ethanol at $800 \mu \mathrm{L}$, then shaken a few times and then centrifuged 2 times with a speed of $6,000 \mathrm{rpm}$ for 15 minutes and a speed of 6,000 rpm for 6 minutes. 70\% ethanol solution is removed, the DNA sediment at the bottom of the tube as a white pellet. The DNA dried at room temperature for about 24 hours, then added with distilled water or TE buffer (10 $\mathrm{mM}$ Tris and $1 \mathrm{mM}$ EDTA, $\mathrm{pH}$ 8.0) at $100 \mu \mathrm{L}$ then stored at $-20^{\circ} \mathrm{C}$ before being used for the next step.

\section{DNA Purity and Quantity Level}

The measurement of purity and quantity level of DNA is carried out using ultra-violet spectrophotometry type thermospektronic genesys model 10 UV (Rochester NY-USA). At $20 \mu \mathrm{L}$ genomic DNA was diluted become $3 \mathrm{~mL}$ (dilution factor 150) and the absorbants measured at 260 and $280 \mathrm{~nm}$ wavelength. To find out the concentration of double-stranded DNA, the below formula is used (Birren et al., 1997):

\section{DNA concentration $(\mathrm{pg} / \mathrm{ml})=\mathrm{A}_{260} \times 50 \times$ liquidify factor}

The purity of the DNA solution can be seen by dividing the value of OD260 with OD280. DNA molecules defined as pure if the ratio of the two values ranges from 1.8 to 2.0. If the ratio value is smaller than 1.8 then there is still protein or phenol contamination in the solution. 


\section{PCR Amplification}

The reaction of DNA amplification using PuReTaq RTG-PCR beads (GE healthcare) further running with PCR Gene Amp System 2700 (Applied Biosystems) programmed in 45 cycles. Amplification was carried out using the PCR method with material composition: $1 \mu \mathrm{L}$ primer $(50 \mathrm{pmol} / \mu \mathrm{L}), 3 \mu \mathrm{t} \mathrm{DNA}$, and $21 \mu \mathrm{L}$ water free RNAse until reaching a total volume of $25 \mu \mathrm{L}$. The micro-PCR tube is inserted in the PCR machine. The PCR cycle used in amplification is one predenaturation cycle at $94^{\circ} \mathrm{C}$ for 2 minutes, to activate the enzyme taq polymerase required 45 cycles with denaturation at $94^{\circ} \mathrm{C}$ for 30 seconds, sticking at $36^{\circ} \mathrm{C}$ for 30 seconds and elongation at 72 for 1,0 minutes and at the end of the PCR 2 minutes of final synthesis are added to ensure all amplification results are in the form of double strand. The PCR results were separated using $2.0 \%$ agarose gel in TBE solution for $1 \times 1.5$ hours at a voltage of 150 volts. The volume of PCR / amplicon yield (which will be migrated) is $3 \mu \mathrm{L}$ and mixed with loading dye $1.0 \mu \mathrm{L}$. The gel is stained with ethidium bromide at $0.5 \mathrm{ng} / \mathrm{mL}$ concentration. The results of DNA electrophoresis were visualized using a UV transluminator.

\section{Primers Screening}

To amplify genomic DNA through PCR, 7 universal primers were used: 6 Operon Technology Kit A primers and $1 \mathrm{M}-13$ primers (Table 1 ). Primers that showing clean genomic DNA amplification were selected for use in all samples in this study.

Table 1. Primer types, alkali sequence, nucleotide length and $\mathrm{G}+\mathrm{C}$ alkali composition contained in the primers selected in this study

\begin{tabular}{lllll}
\hline NO & Primer type & Acid Order $\left(5^{\prime}-3^{\prime}\right)$ & Nucleotides length & $\begin{array}{c}\text { G+C content } \\
(100 \%)\end{array}$ \\
\hline 1 & OPA-3 & AGTCAGCCAC & $10-$ mer & 60,0 \\
2 & OPA-6 & GGTCCCTGAC & $10-$ mer & 70,0 \\
3 & OPA-7 & GAAACGGGTG & $10-$ mer & 60,0 \\
4 & OPA-13 & CAGCACCCAC & $10-$ mer & 70,0 \\
5 & OPA-16 & AGCCAGCGAA & $10-$ mer & 60,0 \\
6 & OPA-20 & GTTGCGATCC & $10-$ mer & 60,0 \\
7 & M-13 & GTAAAACGACGGCCAGT & $17-$ mer & 52,9 \\
\hline
\end{tabular}

Note: $O P A-3,6,7,13,16$ and $20=$ Operon Technology Kit $A$ primers, $A=$ Adenine, $C=C y$ tosine, $G=$ Guanine, and $T=$ Thymine

\section{DATA ANALYSIS}

DNA fragments from the amplification of 3 populations are translated into binary data with the value provision (1) for the presence of DNA fragments and (2) for the absence of the fragment. Scored binary data is used to calculate genetic distance and to compile dendrogram through cluster analysis. Genetic variation was analyzed using TFPGA (Tools For Population Genetic Analysis) (Miller, 1997). The relationship closeness is determined by similarity 
index and genetic distance that showed graphically in dendrogram.

\section{RESULTS AND DISCUSSION}

\section{Random Amplified Polymorphik DNA (RAPD) Profile}

The genomic DNA of Rabbit fish (S. canaliculatus) in the waters population of Luwu Regency, Parepare City, and Takalar Regency using TNES urea preservation solution with Phenol-Chloroform method has been successfully carried out by producing a single fragment with a molecular weight around 23,130 bp, presented in Figure 2. The results shows that the level of DNA purity is sufficient for RAPD analysis with the presence of a clean single string and there is no background (smearing) along the path of DNA genome and DNA genome fragmentation.

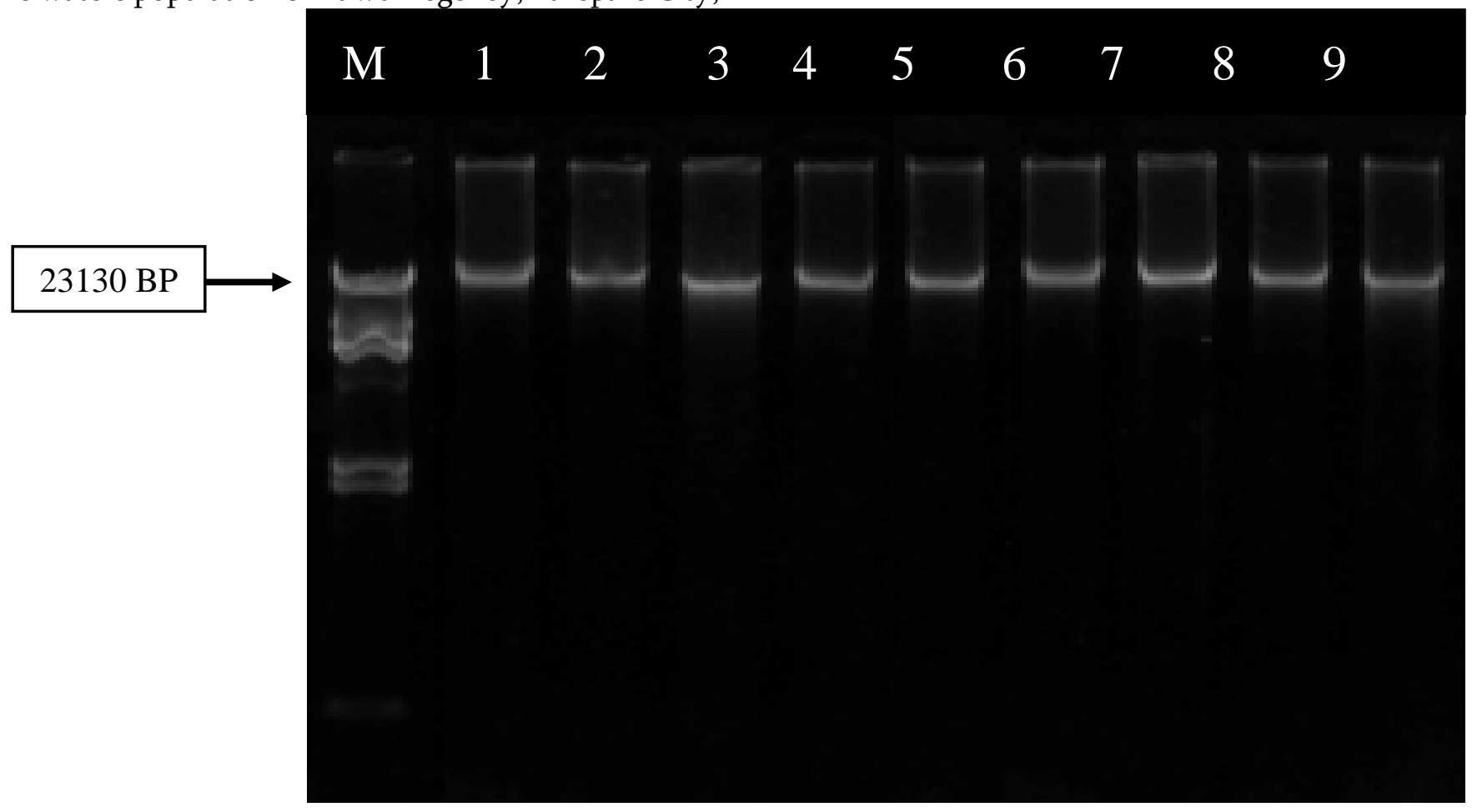

Figure 2. Rabbit fish (S. canaliculatus) DNA Genome electrophoresis result. $M=$ Marker Hind III; number 1-3= Takalar; number 4-6 = Luwu; number 7-9 = Parepare

Rabbit fish DNA each primer has different characters that fragments number and size range are also different. The primers difference is due to the difference in the number of fragments and the amount of amplification produced. The fragments number and percentage (\%) of each primer being used can be seen in table 2 as follows: 
Table 2. Genetic variation of Rabbit fish(S.canaliculatus) in Parepare, Takalar and Luwu waters

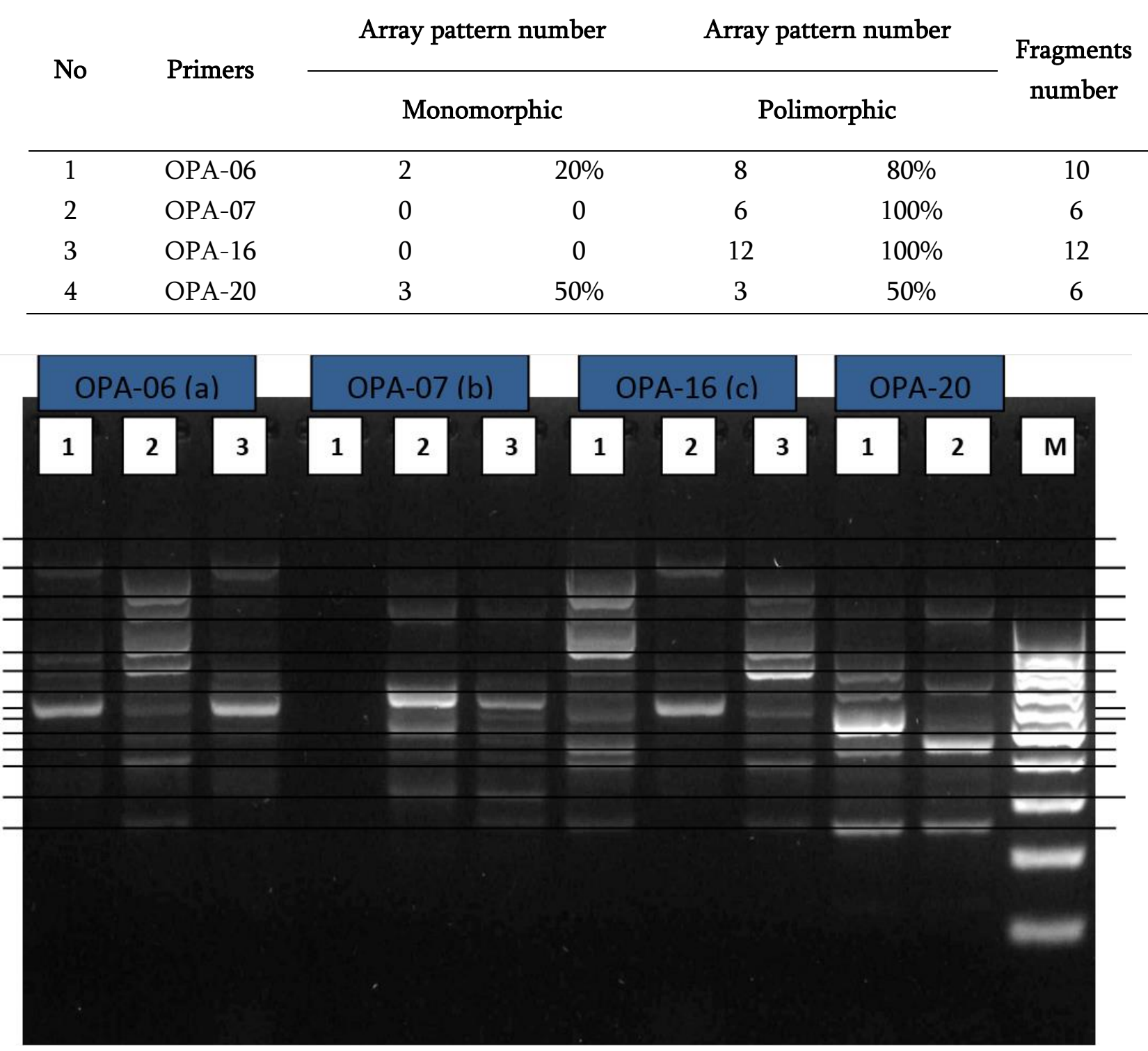

Figure 3. DNA fragmention pattern of $S$ canaliculatus fish RAPD primers screening result. Primer OPA-6,

OPA-7, OPA-16, OPA-20

The results of this study indicate that the number of fragments obtained by OPA-16 is the best primer that produces the highest number of DNA string, 12 of which are all polymorphic string. The second best primer in DNA string in Rabbit fish (Siganus canaliculatus) is OPA-06 with 10 string consist with 8 strings polymorphic strings and 2 strings monomorphic strings. The more polymorphic strings that are read by a primer, the better the primer in reading the alkali arrangement of nitrogen that presence in the sample being tested. Thus, base on this research it is recommended to use two primers that produce the most strings, namely OPA-16 and OPA06.

A total of 9 fish for DNA amplification from three sampling locations using two OPA-6 and OPA-16 primers shows very small differences. The difference in the number of fragments is only due to the primary difference being used, OPA- 6 has 10 fragments and OPA-16 produces 12 fragments. This is caused by difference of nucleotide sequence of each primer or in other words the primary nucleotide sequence of OPA6 has the same genome of the Rabbit fish (S 
canaliculatus) with up to 10 fragments, and OPA-16 has a similarity of up to 12 fragments. Parenrengi (2001) obtained variations in the number of fragments 2-9 in the grouper species, 1-6 in Orange roughl Haplosthus atlantikus (Smith et al., 1997), 6-17 fragments obtained in Tilapia fish, Oreochomis spp (Bardakci and Skibinski, 1994 ) and 1-10 fragments in the catfish channel, Ictalurus spp (Liu et al., 1999), Butini fish 510 fragments (Hamal, 2006).

To see the fragments number, and the polymorphic percentage obtained at the research sites in Luwu, Takalar Regency and Parepare City, using OPA-6 and OPA 16 primers can be seen in table 3 .

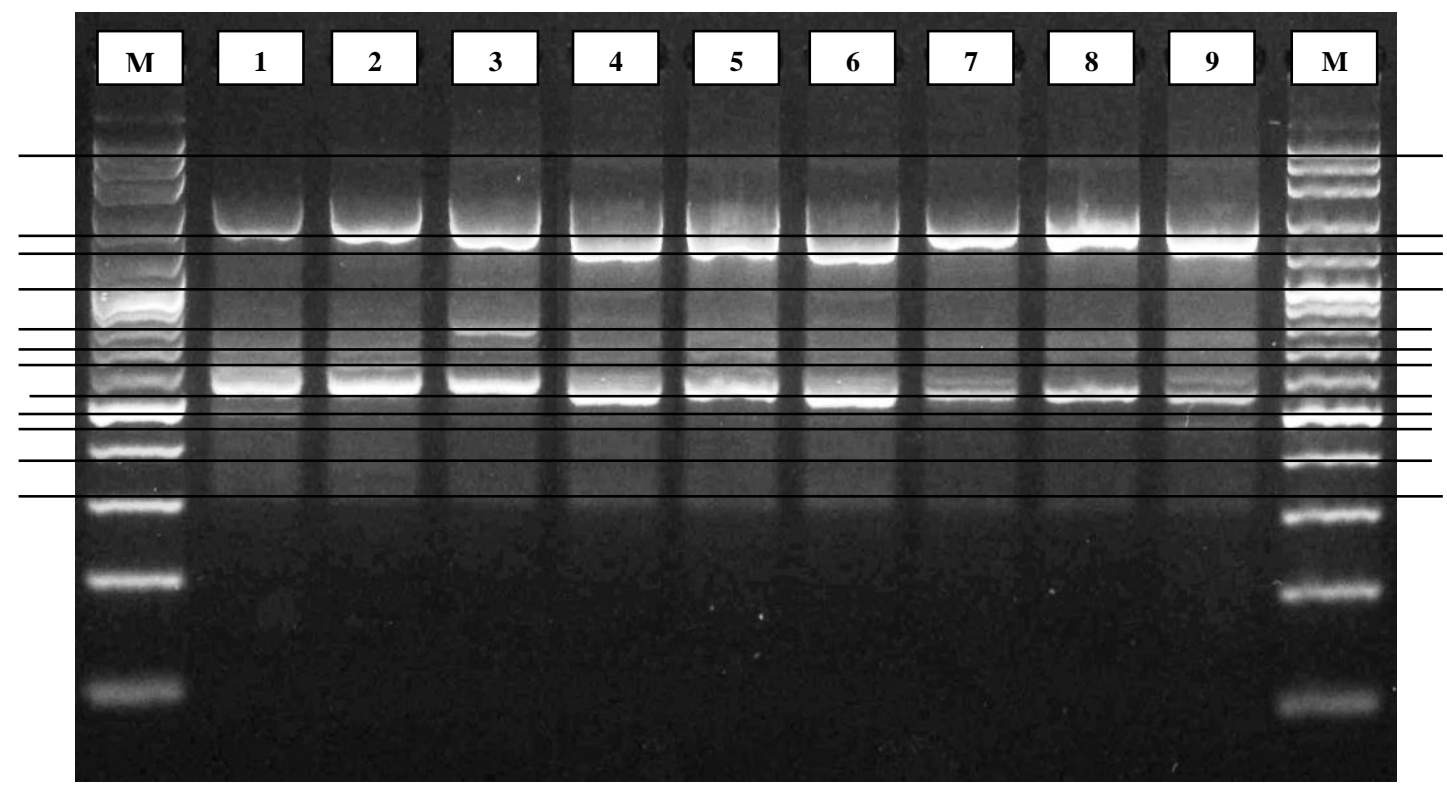

Figure 4. DNA fragmention pattern of $S$ canaliculatus fish RAPD primers screening result. Primer OPA-6. (M= Marker; number 1-3 = Takalar; number 4-6 = Luwu; number $7-9=$ Parepare)

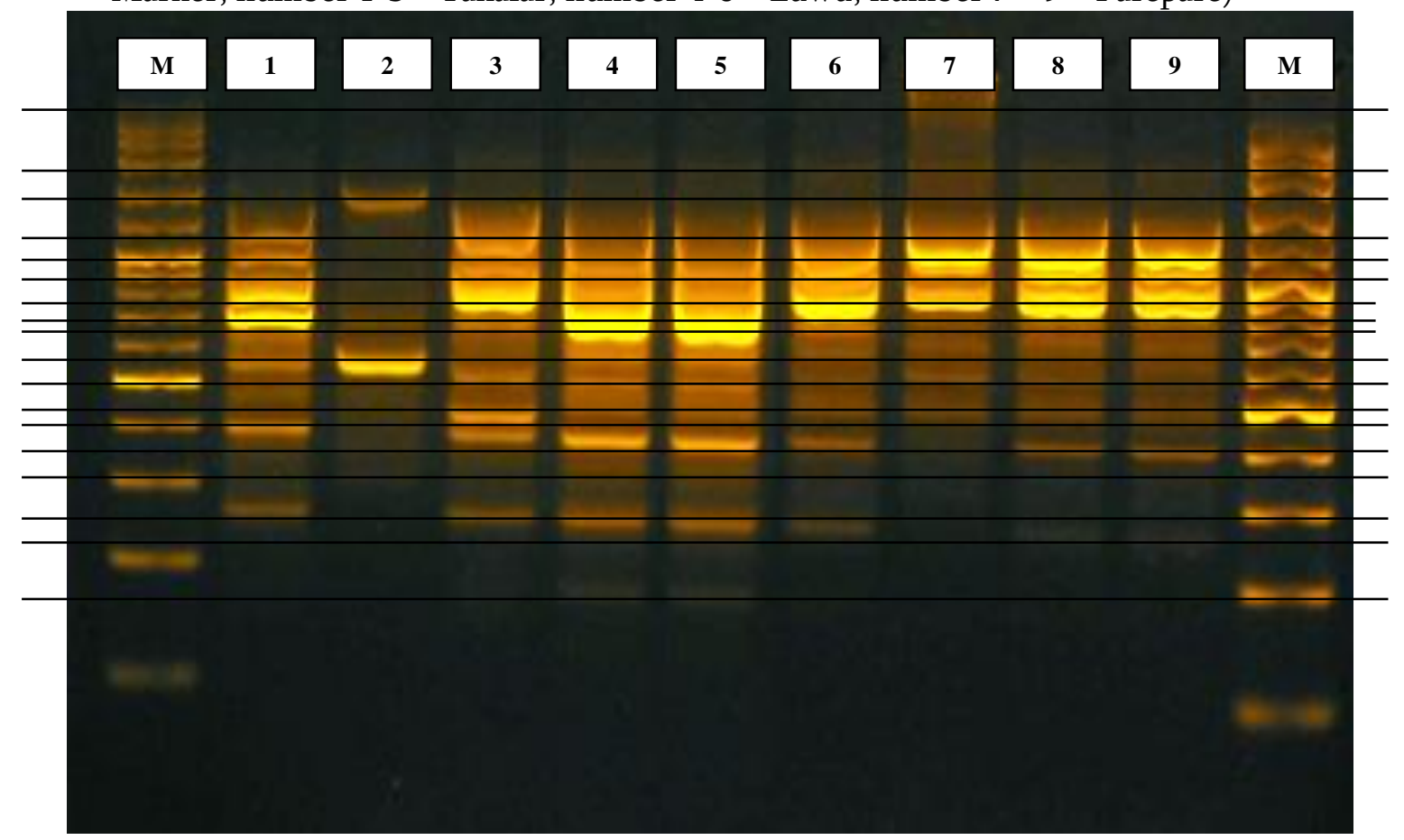

Figure 5. DNA fragmention pattern of $S$ canaliculatus fish RAPD primers screening result. Primer OPA-16. (M= Marker; number 1-3 = Takalar; number 4-6 = Luwu; number 7 -9 = Parepare) 
Table 3. Number of fragments using two OPA-6 and OPA 12 primers in Parepare City Waters, Takalar Regency and Luwu Regency

\begin{tabular}{clcccccc}
\hline \multirow{2}{*}{ No } & \multirow{2}{*}{ Primer } & \multicolumn{3}{c}{ OPA -6 } & \multicolumn{3}{c}{ OPA-12 } \\
\cline { 3 - 8 } & & TK & LW & PR & TK & LW & PR \\
\hline 1 & Fragmentation number & 9 & 7 & 6 & 10 & 9 & 10 \\
2 & Polimorphic number & 8 & 5 & 4 & 9 & 4 & 6 \\
3 & \% Polimorphic & 89 & 71 & 67 & 90 & 44 & 60 \\
\hline Note & $:$ TK = Takalar & & & & & & \\
& $:$ LW = Luwu & & & & & &
\end{tabular}

In the study found that from the three locations and each primer being used showed the number of fragments obtained in OPA- 6 is 22 fragments and in OPA-16 is 29 fragments.

\section{Similarity Index}

Rabbit fish similarity index of the three populations analyzed is $0.7290-0.8644$. The lowest similarity index value obtained in population between Parepare and Luwu Regency with 0.7290. While the highest similarity index value is between Parepare and Takalar Regency population at 0.8644 . The population similarity index of Rabbit fish in Luwu, Parepare and Takalar waters is presented in table 4 .

The high similarity index between Parepare City and Takalar Regency waters population shows that genetic relationship is very close, whereas a low similarity index between Parepare City and Luwu Regency population shows relatively far genetic relationship. Similarity index of Luwu, Parepare and Takalar waters uses 2 primers.
Table 4. The matrix of similarity index of Rabbit fish (S.canaliculatus) genetic variation in Parepare City, Takalar Regency and Luwu Regency waters.

\begin{tabular}{cccc}
\hline $\begin{array}{c}\text { Similarity } \\
\text { Index }\end{array}$ & TK & LW & PR \\
\hline TK & 0 & & \\
LW & 0.8325 & 0 & \\
PR & 0.8644 & 0.7290 & 0 \\
\hline Note $\quad$ TK = Takalar & \\
: LW = Luwu & \\
: PR = Parepare &
\end{tabular}

Lante (2010) observed the Rabbit fish (Siganus guttatus) similarity index from Polman, Barru, and Takalar populations (Makassar Strait) and found between 0.82 - 0.84, while the similarity index from Malili (Bone Bay) and Polman, Barru, and Takalar (Makassar Strait) populations ranging at $0.65-0.68$. Kim (1998) observed similarity index among catfish populations ranging at 0.51 to 0.91 . The similarity index of butini fish populations (Glossogobius matanensis) using OPA-2 and OPA-9 in Mahalona lake is 0.88 , Matano is 0.81 , and Towuti is 0.75 . 


\section{Genetic distance}

The genetic distance of Rabbit fish between the populations of Luwu, Parepare and Takalar waters ranging at $0.1458-0.3161$. The closest genetic distance found in the population of Parepare and Takalar waters which is 0.1458 , while the farthest found etween Luwu and Parepare waters at 0.3161 (Table 5).

Table 5. Genetic distances of Rabbit fish (S. canaliculatus) in the waters of Parepare City, Takalar Regency and Luwu Regency

\begin{tabular}{cccc}
\hline $\begin{array}{c}\text { Genetic } \\
\text { Distance }\end{array}$ & TK & LW & PR \\
\hline TK & 0 & 0.1833 & 0.1458 \\
LW & & 0 & 0.3161 \\
PR & & & 0 \\
\hline
\end{tabular}

\begin{aligned} \hline Note & $: \mathrm{TK}=$ Takalar \\ & $: \mathrm{LW}=$ Luwu \\ & $: \mathrm{PR}=$ Parepare \end{aligned}

Genetic distance of Rabbit fish population between the Takalar and Parepare which has a value of 0.1458 is lower than the genetic distance of between Parepare, Takalar and Luwu which has a value of 0.1833 . The highest genetic distance obtained between Parepare and Luwu Regency with a value of 0.3161 , but this value is lower than the genetic distance value, which is 0.31 - 0.43 found by Lante (2010) between the Makassar Strait and Bone Bay areas.

Genetic closeness between the Takalar and Parepare populations (Makassar Strait) is suspected there has been marriage between the two populations because of in that areas have mixed fluctuatively and seasonally from the direction of the Sulawesi Sea to the Flores Sea throughout the year (Rusman, 2003); and according to Sofian et al., (2006), the relatively close geographical location allows the genetic structure of baronang fish of the two populations to be similar and to be in one group.

According to Parenrengi (2001), that low genetic distance indicates gene flow occurs between the populations. Similarly, the smaller the genetic distance between individuals in a population, the more uniform the population (Pandin, 2000). Furthermore, Soelistyowati (1996) outlines that the loss or the decrease of genetic variation will affect the growth, the development, the fertility as well as the body's resistance to diseases which are important processes in life, production and reproduction.

Several studies have shown that fish genetic distance is closely related to geographical conditions. In Bone bay influenced by the water mass of Flores Sea from the Indonesian Ocean forming isolation of Rabbit fish populations between the Bone bay and the Makassar Strait. Iguchi et al., (1999) stated that isolation due to distance differences was one of the factors considered to affect the rate of gene flow between separate locations and would increase genetic differences.

Thus, from the analysis results of the genetic distance of the Rabbit fish population of Luwu waters (Bone Bay) that are higher than the population of Parepare and Takalar (Makassar Strait), due to the population isolation. Parepare and Takalar (Makassar Strait) population has a close distance and assumed marriage occurs between the two populations, or genetic flow due to the water mass fluctuative and seasonal mixing from the direction of Sulawesi Sea to the Flores Sea throughout the year. 

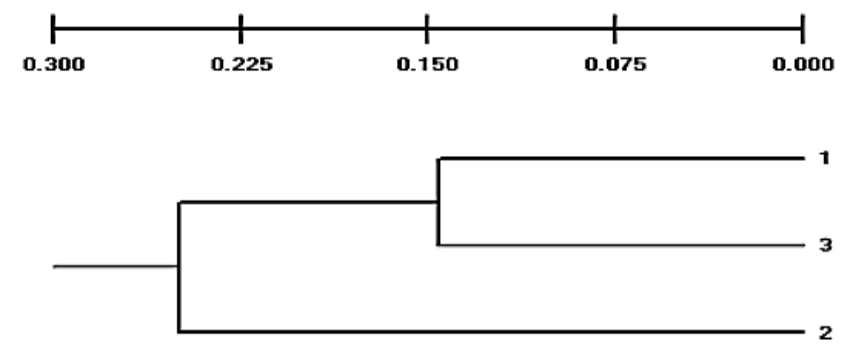

UPGMA Cluster using Nei's (1972) original distance

Node Distance Includes Populations

$10.1458 \quad 13$

$20.2497 \quad 123$

Figure 6. Phylogenetic diagram of Rabbit fish (S. canaliculatus) in the waters of Parepare City (1), Luwu Regency (2) and Takalar Regency (3).

Based on the results of the genetic distances dendogram, obtained two main clusters; the first population of Parepare and Takalar waters and the second is Luwu water population (Figure 6). The genetic distance between the Parepare and Takalar is 0.1458 , while both populations had a genetic distance at 0.2497 with the Luwu waters (Appendix 6). The major genetic distances between Parepare and Luwu population are due to the geographical distance between Luwu and Parepare comparing to Takalar waters.

\section{v. CONCLUSION}

- Similarity index of the three Rabbit fish populations analyzed is around $0.7290-0.8644$. The lowest value is obtained in the population between the waters of Parepare City and Luwu Regency, which is 0.7290 , while the highest value between the population of Parepare City and Takalar Regency at 0.8644 .

- Genetic distance of Rabbit fish between Luwu, Parepare and Takalar waters population ranges from $0.1458-0.3161$. The closest distance is found between the population of Parepare and Takalar waters which is 0.1458 while the farthest distance is between Luwu and Parepare waters at 0.3161 .

\section{SUGGESTIONS}

This research suggest that further research is needed to see the effect of environmental quality on morphometric, meristic and genetic variation on the growth of Rabbit fish species (Siganus canaliculatus) in the previous research area.

\section{VII.REFERENCES}

[1]. Allen G.R. (2000). Marine Fish of South-East Asia. Periplus. Singapura.

[2]. Asahida, T,. T. Kabayashi, K. Saitoh and I. Nayakoya. 1996. Tissue preservation and Total DNA Extraction From Fish Store at Ambient Temperature Using Buffer Containing High Concentration of Urea. Fisheries Science 62 (5) : 727-730

[3]. Burhanuddin I.A, Hutomo M., S. Martosewojo S. \& Djamali A. (1979). Ikan-Ikan Laut Berbisa dan Beracun Di Indonesia. LON - LIPI. Jakarta.

[4]. Burhanuddin I.A., Iwatsuki Y. (2006). The Siganid-Fishes (Siganidae) Of the spermonde. Makassar, South Sulawesi, Indonesia

[5]. Carpenter K.E. (2001). The Living Marine Resources of The Western Central Pacific. FAO. Roma.Volume 6. hal. 3627-3650.

[6]. Dinas Kelautan dan Perikanan. (2012). Fasilitasi Inisiasi Penetapan Status Perlindungan Jenis Ikan Malaja (Siganus sp.)Kabupaten Luwu. Seksi Kelautan Dan Konservasi Bidang Kelautan, Pesisir Dan Perikanan Tangkap. Makassar

[7]. Ghufran, M., \& Kordi H. (2005).Budidaya Ikan Baronang. Rineka Cipta. Jakarta.

[8]. Imanto T dan Suastika M. 2010. Kendala pada pendederan benih ikan baronang lada (siganus canaliculatus) pada keramba jaring apung di perairan pulau sirai, tanjungpinang. Balai Besar Riset Perikanan Budidaya Laut. Gondol. Bali

[9]. Iwatsuki.Y., Burhanuddin I., Djawad I., Motomura H. \& Hidaka K. (2000). A Preliminary 
List of the Epypelagic and Inshore Fishes of Makassar, South Sulawesi, Indonesia, Collected Mainly from Fish Markets between 23-27 Januari 2000, with Notes on Fishery Catch Characteristics. Buletin of the Faculty of Agriculture, Miyazaki University. Japan.

[10]. Jalil., Mallawa A., \& Ali A.S. (2001). Biologi Populasi Ikan Baronang Lingkis (S. Canaliculatus) di Perairan Kecamatan Bua Kabupaten Kab. Luwu. Sulawesi Selatan

[11]. Khaeruddin. (2012). Malaja' Ikan Pavorit datu luwu. Palopo Pos. http://www.palopopos.co.id

[12]. Lante S. (2010). Analisis keragaman genetik populasi ikan Baronang (Siganus guttatus) di Selat Makassar dan Teluk Bone. Program Pascasarjana Universitas Hasanuddin Makassar. Tesis. Universitas Hasanuddin. Makassar

[13]. Saanin H. (1995). Taksonomi dan Kunci Identifikasi Ikan I dan II. Bina Cipta. Bandung.

[14]. Syakhruddin. (2012). Malaja Ikan Khas Karang karangan. Palopo Pos. http://www.palopopos.co.id/?vi=detail\&nid=506 31

[15]. Yunus M. (2005). Perbedaan Karakter morfometrik dan meristik famili Siganidae pada habitat yang berbeda di perairan spermonde. Skripsi. Universitas Hasanuddin. Makassar

\section{Cite this article as :}

Sahabuddin, Prof. Dr. Ambo Tuwo, DEA, Andi Iqbal Burhanuddin, Asmi Citra Malina, "Genetic Variation of Rabbit Fish (Siganus canaliculatus Park, 1797) In the waters of Bone Bay and Makassar Strait ", International Journal of Scientific Research in Science and Technology (IJSRST), Online ISSN : 2395-602X, Print ISSN : 2395-6011, Volume 6 Issue 6, pp. 171-181, November-December 2019. Available at doi : https://doi.org/10.32628/IJSRST196620 Journal URL : http://ijsrst.com/IJSRST196620 